\title{
Catch crop diversity increases rhizosphere carbon input and soil microbial biomass
}

\author{
Norman Gentsch ${ }^{1}$ (D) Jens Boy ${ }^{1} \cdot$ Juan Daniel Kennedy Batalla ${ }^{1} \cdot$ Diana Heuermann $^{2} \cdot$ Nicolaus von Wirén $^{2}$. \\ Dörte Schweneker ${ }^{3}$ • Ulf Feuerstein ${ }^{3}$ • Jonas Groß ${ }^{4}$ • Bernhard Bauer ${ }^{4}$ - Barbara Reinhold-Hurek ${ }^{5}$. Thomas Hurek ${ }^{5}$. \\ Fabricio Camacho Céspedes ${ }^{6} \cdot$ Georg Guggenberger $^{1}$
}

Received: 5 February 2020 / Revised: 29 April 2020 / Accepted: 3 May 2020 / Published online: 23 May 2020

(C) The Author(s) 2020

\begin{abstract}
Catch crops increase plant species richness in crop rotations, but are most often grown as pure stands. Here, we investigate the impacts of increasing plant diversity in catch crop rotations on rhizosphere C input and microbial utilization. Mustard (Sinapis alba L.) planted as a single cultivar was compared to diversified catch crop mixtures of four (Mix4) or 12 species (Mix12). We traced the $\mathrm{C}$ transfer from shoots to roots towards the soil microbial community and the soil respiration in a ${ }^{13} \mathrm{C}$ pulse labelling field experiment. Net $\mathrm{CO}_{2}-\mathrm{C}$ uptake from the atmosphere increased by two times in mix 4 and more than three times in mix 12 . Higher net ecosystem $\mathrm{C}$ production was linked to increasing catch crop diversity and increased belowground transfer rates of recently fixed photoassimilates. The higher rhizosphere $\mathrm{C}$ input stimulated the growth and activity of the soil microbiome, which was investigated by phospholipid fatty acid (PLFA) analyses. Total microbial biomass increased from 14 to $22 \mathrm{~g} \mathrm{~m}{ }^{-2}$ as compared to the fallow and was 18 and $8 \%$ higher for mix 12 and mix 4 as compared to mustard. In particular, the fungal and actinobacterial communities profited the most from the higher belowground $\mathrm{C}$ input and their biomass increased by 3.4 and 1.3 times as compared to the fallow. The residence time of the ${ }^{13} \mathrm{C}$ pulse, traced in the $\mathrm{CO}_{2}$ flux from the soil environment, increased with plant diversity by up to 1.8 times. The results of this study suggest positive impacts of plant diversity on $\mathrm{C}$ cycling by higher atmospheric $\mathrm{C}$ uptake, higher transport rates towards the rhizosphere, higher microbial incorporation and prolonged residence time in the soil environment. We conclude that diversified catch crop mixtures improve the efficiency of $\mathrm{C}$ cycling in cropping systems and provide a promising tool for sustainable soil management.
\end{abstract}

Keywords Catch crops $\cdot$ Cover crops $\cdot$ Agrobiodiversity $\cdot 13 \mathrm{C}$ pulse labelling $\cdot$ Rhizosphere C-transfer $\cdot$ Soil microbiome

\section{Introduction}

Sustainable agriculture poses the challenge of developing innovative farming solutions to maintain or even increase

Electronic supplementary material The online version of this article (https://doi.org/10.1007/s00374-020-01475-8) contains supplementary material, which is available to authorized users.

\section{Norman Gentsch}

gentsch@ifbk.uni-hannover.de

1 Institute of Soil Science, Leibniz Universität Hannover, Herrenhäuser Straße 2, 30459 Hannover, Germany

2 Molecular Plant Nutrition, Leibniz Institute of Plant Genetics and Crop Plant Research Gatersleben, Corrensstraße 3, 06466 Stadt Seeland, Germany productivity without negatively affecting the ecosystem services provided by agricultural landscapes. Catch cropping was identified as an economical and suitable tool for the ecological intensification of cropping systems (Kaye and Quemada
3 Deutsche Saatveredelung AG, Steimker Weg 7,, 27330 Asendorf, Germany

4 Crop Production and Crop Protection, Institute of Biomass Research, University of Applied Science Weihenstephan-Triesdorf, Markgrafenstrasse 16,, 91746 Weidenbach, Germany

5 Department of Molecular Plant Microbiology, University of Bremen, Leobener Straße, 28359 Bremen, Germany

6 University of Georgia, Costa Rica Campus, San Luis de Monteverde, Puntarenas, Costa Rica 
2017; Wittwer et al. 2017; Abdalla et al. 2019). Catch crops, also referred as cover crops, can be integrated between two main crops instead of having a fallow period and can be incorporated into the soil as green manure to fertilize the succeeding crop. The major goal of this practice is the improvement of soil quality and the prevention of soil erosion or leaching losses of postharvest nutrients (Thorup-Kristensen et al. 2003). Therefore, catch crops are valuable tools for nutrient management in crop rotations as they tighten nutrient cycles and improve nutrient use efficiency in agricultural landscapes. Catch crops are able to take on an important role in improving agrobiodiversity and microhabitat restoration (Tsiafouli et al. 2015; Vukicevich et al. 2016). Traditional catch crop systems often display reduced functional diversity by using only a small variety of catch crops mostly grown in pure stands. However, the utilization of catch crops that consist of only one or two species may limit the potential benefits that could be derived from this practice. With the application of diversified catch crop mixtures, broader functional plant performance and thus additional ecosystem services could be achieved. Combining legume and non-legume species in catch crop mixtures, for example, resulted in both high residual nutrient acquisition and green manure services for the following crop (Couëdel et al. 2018).

In order to achieve the maximal benefits of catch cropping, one of the basic aims is the production of a high biomass yield. Increasing shoot biomass was positively related to weed suppression, prevention of nitrate leaching, biomass $\mathrm{N}$ and increasing OC and TN contents in soil (Mazzoncini et al. 2011; Finney et al. 2016). Increasing catch crop diversity, however, has not resulted in higher shoot biomass yields than those of high yielding sole catch crops so far (Finney et al. 2016; Heuermann et al. 2019). However, the green manure effects on the subsequent cash crop do not necessarily depend on aboveground biomass maximization. Rather, the quality of the litter residues, namely, a lower $\mathrm{C} / \mathrm{N}$ ratio in litter, appears to have the highest effect on crop yield services (Finney et al. 2016; Couëdel et al. 2018). Combining legume and nonlegume species is therefore a valuable tool for adjusting catch crop shoot biomass quality and mineralization patterns during subsequent cash crop growth. Furthermore, synergistic effects between plants, such as $\mathrm{N}$ facilitation (neighbouring plants benefit from the additional $\mathrm{N}$ input from $\mathrm{N}_{2}$-fixing symbionts), impact plant growth performance and biomass yields (Faget et al. 2013). But also in the absence of legumes, positive relationships between plant diversity and biomass productivity have been demonstrated (Van Ruijven and Berendse 2009).

Perhaps the most important advantage of mixed catch crops comes from the rhizosphere. However, root performance in sole versus mixed plantings and its impact on nutrient acquisition have been poorly studied thus far. Our latest research demonstrated that catch crop mixtures overyield root biomass than that in single-species plantings (Heuermann et al. 2019). This higher root biomass yield was characterized by interspecies competition, where some species responded with higher root/shoot ratios but also with synergism between species and root growth. The same lack of information exists about the role of catch crop rhizodeposits and the effect of rhizosphere $\mathrm{C}$ input on the soil microbiome and $\mathrm{C}$ sequestration. Approximately $40 \%$ of the photosynthates produced by plants are translocated towards the rhizosphere within hours (Kumar et al. 2006). Rhizodeposition is closely related to root biomass, and for a few Brassica species, it was shown that catch crops store more $\mathrm{N}$ belowground when rhizodeposits were considered (Kanders et al. 2017). Root exudates enhance microbial activity and provide exoenzymes that mobilize nutrients from the soil (Kumar et al. 2006). Root mucilage, for example, is an important $\mathrm{C}$ source for soil microorganisms and increase their drought stress resistance (Ahmed et al. 2018). The $\mathrm{C}$ and $\mathrm{N}$ supply of roots to microbial utilization and nutrient mobilization depends on the plant species and was found generally higher for legume than for non-legume plants (Wichern et al. 2007). Increasing the rhizosphere input from the application of catch crop mixtures could therefore tighten element cycling in soil and stimulate $\mathrm{C}$ sequestration.

Soil microorganisms provide essential ecosystem services in farmland soils such as organic matter (OM) decomposition, nutrient cycling or maintenance of soil structure (Paul 2007; Bender et al. 2016). Plants and microorganisms have developed intimate relationships helping them to exchange nutrients, maintain plant health and productivity (Chaparro et al. 2012). A recent synthesis highlighted the overall impacts of catch/cover crops on the microbial community in a wide range of arable soils (Kim et al. 2020). The meta-analyses found that catch crops increase the overall abundance, activity and diversity of soil microorganisms. But also the soil microbial functional diversity and their substrate use efficiency showed a strong positive response to catch crop treatments (Nivelle et al. 2016). The plant species applied as catch crops are important drivers of the soil microbiome and the selection of desired species or mixtures have been suggested as tools for their management (Finney et al. 2017).

Catch crop research during recent decades has focused mostly on the performance of single species, while species diversity has remained poorly considered. The aim of the study was to test how catch crop diversity affects $\mathrm{C}$ cycling from the atmosphere through the plant-soil-microbiome system. More specifically, the efficiency for $\mathrm{C}$ uptake and the belowground input of recently photosynthesized $\mathrm{C}$ products and their partitioning in the rhizosphere was investigated. The allocation and incorporation of $\mathrm{C}$ compounds in belowground compartments is well known to occur within hours after its assimilation and the turnover of rhizosphere products spans hours to few days (Jones et al. 2009). We therefore used an in situ ${ }^{13} \mathrm{C}$ pulse labelling experiment to follow these rapid 
allocation processes. A single cultivar was compared with catch crop mixtures of different diversity levels (4 and 12 species). We hypothesized that diversified catch cropping systems would (I) increase photosynthetic $\mathrm{C}$ fixation with higher transport rates of newly assimilated $\mathrm{C}$ to the roots, (II) stimulate microbial growth through higher $\mathrm{C}$ utilization when $\mathrm{C}$ reaches the rhizosphere and (III) prolongate the $\mathrm{C}$ cycling throughout the plant-soil-microbiome system.

\section{Material and methods}

\section{Field site and crop rotation}

The experiment was conducted on long-term field sites at the Asendorf field station maintained by the Deutsche Saatveredelung (DSV) $70 \mathrm{~km}$ north of Hannover, Germany (49 $\mathrm{m}$ above sea level [a.s.1.], 52 $45^{\prime} 48.4^{\prime \prime} \mathrm{N} 9^{\circ} 01^{\prime} 24.3^{\prime \prime} \mathrm{E}$ ). The climate is temperate oceanic with an annual mean temperature of $9.3^{\circ} \mathrm{C}$ and a mean annual precipitation of $751 \mathrm{~mm}$ (long-term mean, 1981-2010). The soil developed from a shallow loess cover over glaciofluvial sand $(>50 \mathrm{~cm})$ and was classified as a Stagnic Cambisol according to the World Reference Base (IUSS Working Group WRB 2014). The soil texture was a silty loam with low heterogeneity across the field site (basic soil properties in Table 1). Soil $\mathrm{pH}$ was slightly acidic ( $\mathrm{pH}$ 6.0-6.4) and soil organic $\mathrm{C}$ decreased from $1.6 \%$ in the topsoil $(0-30 \mathrm{~cm})$ to $0.8 \%$ in the subsoil $(30-60 \mathrm{~cm})$.

The experiment was conducted as a fully randomized splitplot design with three field replications per treatment. In total, 12 plots $9 \times 9 \mathrm{~m}$ in size (including $0.7 \mathrm{~m}$ edges) were established. For monitoring of the mineral $\mathrm{N}$ pools, $10 \mathrm{~g}$ of fresh soil material was extracted with $0.0125 \mathrm{M} \mathrm{CaCl}_{2}$ at a $1: 4$ $(w / v)$ soil/solution ratio, filtered and analysed for exchangeable $\mathrm{NH}_{4}{ }^{+}$and $\mathrm{NO}_{3}{ }^{-}$using an autoanalyser (SAN-plus, Skalar Analytical B.V., The Netherlands). The results were corrected for the water content of the soil. Plant-available nutrient content during the experiment is provided in Table S1 (supplementary material).

The catch crops were included in a conventionally managed 2-year crop rotation with winter wheat (Triticum aestivum L.) in the first year and maize (Zea mays L.) in the second year. Fertilization of the main crops followed the practical recommended rates for mineral fertilizers (wheat in $\mathrm{kg} \mathrm{ha}^{-1}: 140 \mathrm{~N}, 11 \mathrm{P}, 133 \mathrm{~K}, 81 \mathrm{~S}, 22 \mathrm{Mg}$; maize in $\mathrm{kg} \mathrm{ha}^{-1}: 173 \mathrm{~N}, 39 \mathrm{P}, 133 \mathrm{~K}, 56 \mathrm{~S}, 9 \mathrm{Mg}$ ). The wheat straw remained on the field and was incorporated into the soil by a power harrow. Four treatments were investigated: (i) fallow with no catch crop treatment; (ii) mustard (Sinapis alba L.) as a single crop; (iii) mix 4, a mix of white mustard, lacy phacelia (Phacelia tanacetifolia BENTH.), bristle oat (Avena strigosa SCHREB.) and Egyptian clover (Trifolium alexandrinum L.); and (iv) a commercial 12-species catch crop mix (TerraLife $\odot$ Maize-Pro TR Greening, DSV, Lippstadt, Germany). The latter, referred to as mix 12, was $23 \%$ legumes (by dry mass), namely, field pea (Pisum sativum L.), crimson clover (Trifolium incarnatum L.), alsike clover (Trifolium hybridum L.), Persian clover (Trifolium resupinatum L.) and Hungarian vetch (Vicia pannonica CRANTZ.), and nonlegume species, namely, sorghum (Sorghum sudanense STEUD.), common flax (Linum usitatissimum L.), lacy phacelia, deeptill radish (Raphanus sativus L.), ramtil (Guizotia abyssinica CAss.), sunflower (Helianthus annuus L.) and camelina (Camelina sativa L.). The function of mustard as a Brassicaceae in mix 12 was taken over Raphanus sativus and Camelina sativa. Several publications have reported similar levels of glucosinolate production by mustard and radish that can be used for biological pest and disease control (Kirkegaard and Sarwar 1998; Reddy 2013; Park et al. 2017).

The fallow period was maintained by mechanical weeding. Catch crops were sown on 22 August 2016, and the experiment was performed in the stages of stem elongation and shoot development from 18.10.2016 to 14.11.2016. Seeding rates were adapted from practical recommended rates and aimed at maximum biomass development and optimal growth performance (Table S2, supplementary material). Plant density was counted for $2 \mathrm{~m}$ along the sowing row, two times per plot.

\section{Experimental setup and ${ }^{13} \mathrm{C}$ pulse labelling}

The $\mathrm{C}$ transfer within the plant-soil-microbial system was studied by an in situ ${ }^{13} \mathrm{CO}_{2}$ pulse labelling experiment. Single pulse labelling has been proposed as appropriate method to estimate short-term processes of recently assimilated C in various above- and belowground $\mathrm{C}$ pools (Kuzyakov and Gavrichkova 2010). The short pulse allowed the differentiation between decomposers of rhizodeposits and that of native

Table 1 Basic soil properties of the experimental field site (mean values \pm standard error)

\begin{tabular}{clllllllll}
\hline Soil depth $(\mathrm{cm})$ & $\mathrm{pH}$ & $\mathrm{BD}\left(\mathrm{g} \mathrm{cm}^{-3}\right)$ & Clay $(\%)$ & Silt $(\%)$ & Sand $(\%)$ & OC $(\%)$ & $\mathrm{TN}(\%)$ & $\delta^{13} \mathrm{C}(\%)$ & $\delta^{15} \mathrm{~N}(\%)$ \\
\hline $0-10$ & $6.05 \pm 0.06$ & $1.24 \pm 0.01$ & $7.68 \pm 0.13$ & $74.24 \pm 0.38$ & $18.08 \pm 0.33$ & $1.67 \pm 0.05$ & $0.15 \pm 0.00$ & $-26.85 \pm 1.13$ & $6.94 \pm 0.57$ \\
$10-30$ & $6.18 \pm 0.05$ & $1.30+0.01$ & $7.56 \pm 0.14$ & $74.60 \pm 0.42$ & $17.84 \pm 0.37$ & $1.60 \pm 0.04$ & $0.15 \pm 0.00$ & $-27.96 \pm 0.06$ & $7.68 \pm 0.07$ \\
$30-60$ & $6.41 \pm 0.03$ & $1.62 \pm 0.03$ & $6.39 \pm 0.29$ & $72.69 \pm 1.38$ & $20.93 \pm 1.25$ & $0.81 \pm 0.04$ & $0.08 \pm 0.00$ & $-27.72 \pm 0.08$ & $7.50 \pm 0.10$ \\
\hline
\end{tabular}


soil OM. Prior to the labelling treatment, the photosynthetic $\mathrm{CO}_{2}$ uptake rate of the plants was measured. For this, a $0.75 \times$ $1.20 \times 1.12$-m-sized steel-frame chamber (width $\times$ length $\times$ height) covered by transparent polypropylene foil and plexiglass was placed on the catch crop plot and placed $10 \mathrm{~cm}$ deep into the soil. The $\mathrm{CO}_{2}$ concentration inside the chamber was monitored with an infrared gas analyser (LI8100, LI-COR Inc., Lincoln, NE) that was directly connected to the chamber in a closed loop. The chamber was equipped with fans to maintain air circulation and prevent air layering. The temperature and moisture inside the chamber were monitored with an ambient monitoring data logger (DL-181THP, Voltcraft, Hirschau, Germany). Soil respiration (without plants) in each plot was measured using a 20 -cm survey chamber (LI-COR Inc., Lincoln, NE) with attached soil collars, which were placed $6 \mathrm{~cm}$ deep into the soil. The photosynthetic $\mathrm{CO}_{2}-\mathrm{C}$ uptake by the plants on the day of labelling (before label application) was measured from the flux inside the chamber and referred to as the net ecosystem exchange (NEE).

The NEE is defined as the $\mathrm{CO}_{2}-\mathrm{C}$ flux from the ecosystem to the atmosphere. Negative NEE values represent the net $\mathrm{CO}_{2}-\mathrm{C}$ uptake at the experimental plots, and positive values represent the opposite.

The ${ }^{13} \mathrm{CO}_{2}$ pulse inside the chamber was applied 20 min after starting the gas measurements. Twenty millilitres of $4 \mathrm{M}$ sulphuric acid $\left(\mathrm{H}_{2} \mathrm{SO}_{4}\right)$ was injected with a syringe into a solution of distilled water containing $2 \mathrm{~g}$ sodium carbonate $\left(\mathrm{Na}_{2}{ }^{13} \mathrm{CO}_{3}\right)$ enriched with ${ }^{13} \mathrm{C}$ to 99 atom\%. The pulse increased the concentration inside the chamber by $350 \mathrm{ppm}$ to the total maximum between 500 and $670 \mathrm{ppm}$, depending on the NEE between the treatments. The chamber was removed $30 \mathrm{~min}$ after labelling and allowed to aerate before subsequent installation.

\section{Sampling and $\delta^{13} \mathrm{C}$ measurements}

Unlabelled reference samples and labelled samples were taken on days 0 (day of labelling), 1, 6, 11, 16 and 21 following the label application. The measurements of soil respiration with the LI-COR were taken on the same days, and additional samples were taken from the air stream inside the survey chamber for ${ }^{13} \mathrm{CO}_{2}$ measurements. Additionally, the soil air was sampled from different soil depths $(10,30$ and $60 \mathrm{~cm})$. For this, soil air suction cups (ecoTech $\mathrm{GmbH}$, Bonn, Germany), $2.5 \mathrm{~cm}$ in diameter, were installed 2 weeks in advance. All gas samples were taken by gas-tight syringe and injected into $12 \mathrm{ml}$ Labco Excetainers $($, which were preevacuated and flushed with He three times. All gas samples were analysed for the concentration and $\delta^{13} \mathrm{C}$ of $\mathrm{CO}_{2}$ with a gas chromatograph coupled to an isotope mass spectrometer
(GC-Box connected to a Delta plus XP system, Thermo Fisher Scientific, Bremen, Germany).

Plant and soil samples were taken from five microplots $(38 \times 30 \mathrm{~cm})$ that were previously covered by the labelling chamber. On each sampling day, one microplot was harvested destructively. Afterwards, the whole soil volume of the microplot was dug out to a $20 \mathrm{~cm}$ soil depth, and plants were carefully removed to avoid root destruction. The rest of the soil was sieved to $2 \mathrm{~mm}$, and the remaining root fragments were recovered. The roots were washed in $\mathrm{H}_{2} \mathrm{O}_{\text {dest }}$, and the plants were divided into roots and shoots. The total dry weight (DW) was determined after drying at $60^{\circ} \mathrm{C}$ for $36 \mathrm{~h}$, and shoot and root biomass were calculated per square metre. Note that the presented root biomass is only representative of the top $20 \mathrm{~cm}$ and did not account for deeper rooting layers. The OC and $\delta^{13} \mathrm{C}$ values of the plant and soil samples were measured by an Elementar IsoPrime 100 IRMS (IsoPrime Ltd., Cheadle Hulme, UK) coupled to an Elementar Vario MICRO cube EA $\mathrm{C} / \mathrm{N}$ analyser (Elementar Analysensysteme GmbH, Hanau, Germany).

\section{Phospholipid fatty acid analyses}

Samples for phospholipid fatty acid (PLFA) analyses were taken from 0 to 10 and 20 to $30 \mathrm{~cm}$ soil depths, stored in cryovials and directly placed on dry ice for transport to the laboratory (the 10-20 cm layer was not analysed for capacity reasons). The PLFA extraction followed the method of Gunina et al. (2014) with some modifications as described by Bischoff et al. (2016). Details of our methods can be found in these two publications. In total, 18 PLFAs were analysed, and their sum expressed per $\mathrm{g}$ dry soil was used as a proxy for total microbial biomass in soil. The following functional groups were calculated from specific PLFA markers: fungi

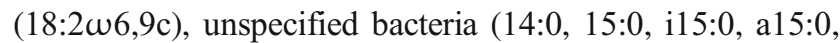

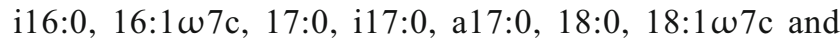
Cy19:0), actinobacteria (10Me16:0), gram-positive bacteria (i15:0, a15:0, i16:0,i17:0, a17:0), gram-negative bacteria

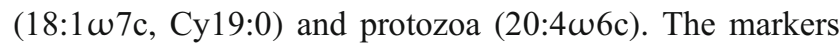
for fungi and bacteria were used to calculate the fungi to bacteria ratio. The microbial PLFA biomass was monitored at days $0,1,11$ and 21 after label application.

\section{Excess ${ }^{13} \mathrm{C}$ in different compartments}

The incorporation of ${ }^{13} \mathrm{C}$ into plants, microbial biomass and soil respiration was calculated as the excess ${ }^{13} \mathrm{C}$. The excess ${ }^{13} \mathrm{C}$ is the difference between the ${ }^{13} \mathrm{C}$ signal of the unlabelled control and the labelled sample. The isotope value was expressed in delta notation relative to the Vienna Pee Dee Belemnite standard $\left(\mathrm{R}_{\mathrm{VPDB}}\right)$. Thereafter, the amount of ${ }^{13} \mathrm{C}$ in the sample was calculated in atom\%: 


$$
\text { atom } \%=\frac{100 \times R_{\mathrm{VPDB}} \times\left(\frac{\delta^{13} C}{100}+1\right)}{1+R_{\mathrm{VPDB}} \times\left(\frac{\delta^{13} C}{100}+1\right)}
$$

The fractional abundance of the label in a sample was calculated by the following equation:

Fractional abundance $=\frac{\text { atom } \%_{\mathrm{S}}-\text { atom } \%_{\mathrm{C}}}{100}$

where atom $\%_{\mathrm{S}}$ is the ${ }^{13} \mathrm{C}$ value in the sample and atom $\%_{\mathrm{C}}$ is the ${ }^{13} \mathrm{C}$ value in the unlabelled control. The excess ${ }^{13} \mathrm{C}$ in plant compartments (in $\mathrm{mg}{ }^{13} \mathrm{C} \mathrm{m}^{-2}$ ) was calculated by multiplication of the fractional abundance and the plant $\mathrm{C}$ in roots and shoots per area $\left(\mathrm{g} \mathrm{m}^{-2}\right)$. For the excess

${ }^{13} \mathrm{C}$ in soil gases, the fractional abundance was multiplied by the quotient of the $\mathrm{CO}_{2}-\mathrm{C}$ concentration in soil air and the volume of the soil air suction cups and expressed in $\mu \mathrm{g} \mathrm{dm}{ }^{-3}$. The ${ }^{13} \mathrm{C}$ flux from soil was calculated by the Keeling plot method according to Pataki et al. (2003) and multiplied by the fractional abundance to calculate the excess ${ }^{13} \mathrm{C}$ in respiration products. For each PLFA marker, the fractional abundance was multiplied by the total amount of the marker in the sample, and the excess ${ }^{13} \mathrm{C}$ was expressed in $\mathrm{ng} \mathrm{g}^{-1}$ soil $^{-1}$. The mean residence time (MRT) of the ${ }^{13} \mathrm{C}$ in soil respiration was calculated by fitting the excess ${ }^{13} \mathrm{C}$ to a one-pool first-order exponential decay function: $C_{(t)}=C_{0} \times e^{-k t}$, with $\mathrm{k}$ as the decay rate constant, $\mathrm{C}_{(\mathrm{t})}$ as the quantity of ${ }^{13} \mathrm{C}$ at time after labelling (t) and $\mathrm{C}_{0}$ as the initial quantity of excess ${ }^{13} \mathrm{C}$. The mean residence time was the reciprocal function of $\mathrm{k}$. The summed recovery of the label in different compartments was between 21 and $51 \%$ of the applied ${ }^{13} \mathrm{C}$ (Table S3). On average, between 87 and $91 \%$ of the recovered ${ }^{13} \mathrm{C}$ was found in shoots, and 13-9\% was found in belowground compartments (Fig. S3).

\section{Statistics}

The differences between treatments (catch crop variant) were evaluated by linear mixed effects models (LMM) to account for the repeated measurements at different dates and the hierarchical nesting of a given sample per plot. The catch crop variant (fallow, mustard, mix 4, mix 12) was set as a fixed effect, while sampling time and plot were set as random effects. Residuals were checked for normality, and log transformation was applied to the data when needed. All statistical analyses and figures were performed in $\mathrm{R}$ version 3.4.0 ( $\mathrm{R}$ Core Team 2017). Means and standard errors (SE) are presented in figures, and small letters denote significantly different groups as determined from the linear mixed models.

\section{Results}

\section{Plant biomass and net ecosystem exchange}

The average dry matter shoot biomass of the catch crops ranged between $35.0 \pm 3.3$ and $39.1 \pm 3.3 \mathrm{dt} \mathrm{ha}^{-1}$ and was not significantly different among treatments (Table 2). The root biomass of mix 12 at the $0-20 \mathrm{~cm}$ soil depth was $24 \%$ higher $\left(4.3 \pm 0.5 \mathrm{dt} \mathrm{ha}^{-1}\right)$ than that of mustard $(3.3 \pm$ $\left.0.3 \mathrm{dt} \mathrm{ha}^{-1}\right)$ and $33 \%$ higher than that of mix $4(2.9 \pm$ $0.3 \mathrm{dt} \mathrm{ha}^{-1}$ ), which was significant (Table 2). Lower OC concentrations were found in the shoot and root litter of mix 12, which translated into lower $\mathrm{C} / \mathrm{N}$ ratios and higher root biomass $\mathrm{N}$ compared to those of mix 4 and mustard (Table 2). Despite the higher seeding density in the two mixed crops compared to that of pure mustard (Table S2), the plant density (plants per $\mathrm{m}^{2}$ ) decreased in the order mustard $(302.6 \pm 34.3)$, mix $4(234.0 \pm 15.5)$ and mix $12(143.4 \pm 6.6)$.

As the NEE was calculated based on gas exchange rates between the atmosphere and the plant-soil system, this parameter best describes the efficiency of atmospheric $\mathrm{C}$ uptake

Table 2 Parameters of catch crop shoot biomass and roots biomass in 0-20 $\mathrm{cm}$ soil depth (mean values \pm standard error). Small letters denote significant differences between the catch crop treatments $(p<0.05)$

\begin{tabular}{|c|c|c|c|c|c|}
\hline Catch crop & $\mathrm{OC}(\%)$ & $\mathrm{TN}(\%)$ & Biomass (dt DW ha ${ }^{-1}$ ) & OC in biomass $\left(\mathrm{dt} \mathrm{ha}^{-1}\right)$ & $\mathrm{TN}$ in biomass $\left(\mathrm{kg} \mathrm{ha}^{-1}\right)$ \\
\hline \multicolumn{6}{|l|}{ Shoots } \\
\hline Mustard & $39.85 \pm 0.5 b$ & $2.24 \pm 0.14 \mathrm{a}$ & $34.98 \pm 3.31 \mathrm{a}$ & $13.88 \pm 1.27 \mathrm{a}$ & $76.69 \pm 8.58 \mathrm{a}$ \\
\hline Mix 4 & $39.03 \pm 0.52 \mathrm{~b}$ & $2.13 \pm 0.13 \mathrm{a}$ & $36.62 \pm 2.84 \mathrm{a}$ & $14.13 \pm 0.97 \mathrm{a}$ & $76.42 \pm 6.17 \mathrm{a}$ \\
\hline Mix 12 & $37.08 \pm 0.6 \mathrm{a}$ & $2.37 \pm 0.16 \mathrm{a}$ & $39.06 \pm 3.31 \mathrm{a}$ & $14.59 \pm 1.34 \mathrm{a}$ & $92.40 \pm 10.94 \mathrm{a}$ \\
\hline \multicolumn{6}{|l|}{ Roots } \\
\hline Mustard & $41.51 \pm 0.48 \mathrm{~b}$ & $1.65 \pm 0.11 \mathrm{a}$ & $3.31 \pm 0.32 \mathrm{ab}$ & $1.37 \pm 0.13 \mathrm{a}$ & $5.5 \pm 0.64 \mathrm{a}$ \\
\hline Mix 4 & $40.07 \pm 0.55 \mathrm{~b}$ & $1.60 \pm 0.15 \mathrm{a}$ & $2.89 \pm 0.33 \mathrm{a}$ & $1.14 \pm 0.13 \mathrm{a}$ & $4.69 \pm 0.76 \mathrm{a}$ \\
\hline Mix 12 & $35.93 \pm 0.65 \mathrm{a}$ & $1.92 \pm 0.16 \mathrm{a}$ & $4.34 \pm 0.46 b$ & $1.56 \pm 0.17 \mathrm{a}$ & $8.40 \pm 1.16 b$ \\
\hline
\end{tabular}




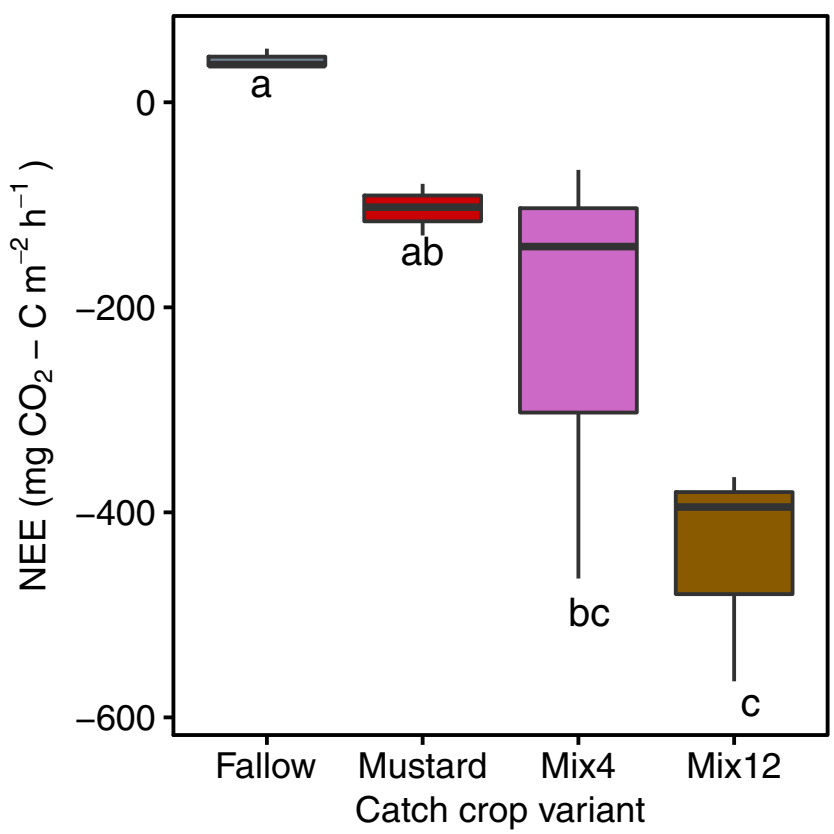

Fig. 1 Net ecosystem exchange (NEE) of C between catch crop treatments. Bars represent means $\pm \mathrm{SE}$; lowercase letters denote significant differences $(p<0.01)$ between treatments

versus respiration losses between treatments. The NEE decreased significantly with increasing catch crop diversity (Fig. 1), suggesting increasing $\mathrm{CO}_{2}$-C uptake from the atmosphere. In comparison to that of the pure mustard treatment, NEE increased by two times when catch crops were grown in a mix of four species and more than three times in mix 12. The lack of plant cover in the fallow treatment resulted in no primary production and a positive NEE of $41.2 \pm 5.5 \mathrm{mg} \mathrm{m}^{-2} \mathrm{~h}^{-1}$. This reflects a constant $\mathrm{C}$ loss from the fallow due to heterotrophic soil respiration to the atmosphere. The decreasing plant density with catch crop diversity resulted in a much higher efficiency of the $\mathrm{C}$ uptake of individual plants in mixed catch crops (Fig. S6).

\section{Belowground $\mathrm{C}$ allocation and $\mathrm{CO}_{2}$ efflux}

The uptake of plant-assimilated $\mathrm{C}$ into the shoots and roots was calculated as excess ${ }^{13} \mathrm{C}$ from the label pulse and traced for 20 days after application. The recovery rate of ${ }^{13} \mathrm{C}$ in different compartments (Table S3) $24 \mathrm{~h}$ after application was significantly $(p<0.05)$ lower for mustard $(24 \pm 2 \%)$ than for mix $4(36 \pm 8 \%)$ and mix $12(37 \pm 7 \%)$. The variability within the excess ${ }^{13} \mathrm{C}$ in the bulk soil was large, and no significant differences could be detected among the treatments (Fig. S4). As a general trend, the excess ${ }^{13} \mathrm{C}$ in the bulk soil reached its maximum at day 11 after labelling, except in mix 12 at 20 $30 \mathrm{~cm}$ depth, with the maximum at the end of the experiment (Fig. S4b). The soil compartment only contributed between 1 and $4 \%$ of the recovered ${ }^{13} \mathrm{C}$ (Fig. S3).

The amount of excess ${ }^{13} \mathrm{C}$ in shoots was similar between mix 12 and mix 4 but significantly higher than that in mustard (Fig. 2b). On average, $43 \pm 3 \%$ less ${ }^{13} \mathrm{C}$ was assimilated in mustard shoots compared to more diverse catch crops. The excess ${ }^{13} \mathrm{C}$ in roots was not different between mix 4 and mustard (Fig. 2a), but the amount in those treatments was significantly different $(p<0.001)$ from that in mix 12 . The latter allocated $11.8 \pm 2.35 \%$ of the assimilated $\mathrm{C}$ belowground $24 \mathrm{~h}$ after label application, while for mix 4 and mustard, the allocations were only $8.6 \pm 0.2 \%$ and $10.9 \pm 1.2 \%$, respectively (Fig. S3). The higher belowground transfer corresponded to a significantly larger root biomass in mix 12 than in mustard and mix 4 (Table 2).
Fig. 2 Excess ${ }^{13} \mathrm{C}$ in roots (a) and shoots (b) of catch crops after labelling. Treatments are indicated by symbol shapes and colours. Symbols represent means \pm SE; lowercase letters denote significant differences $(p<0.01)$ between treatments

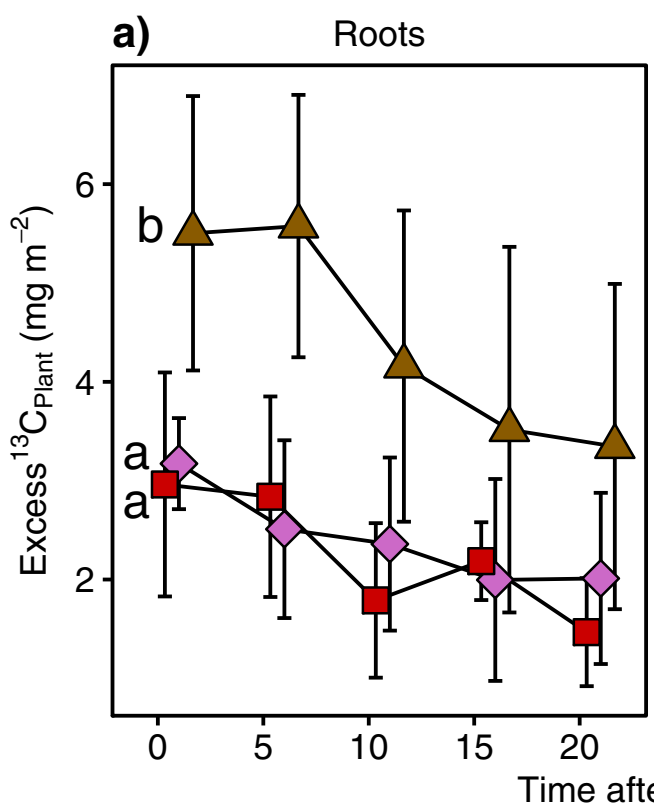

b) Shoots

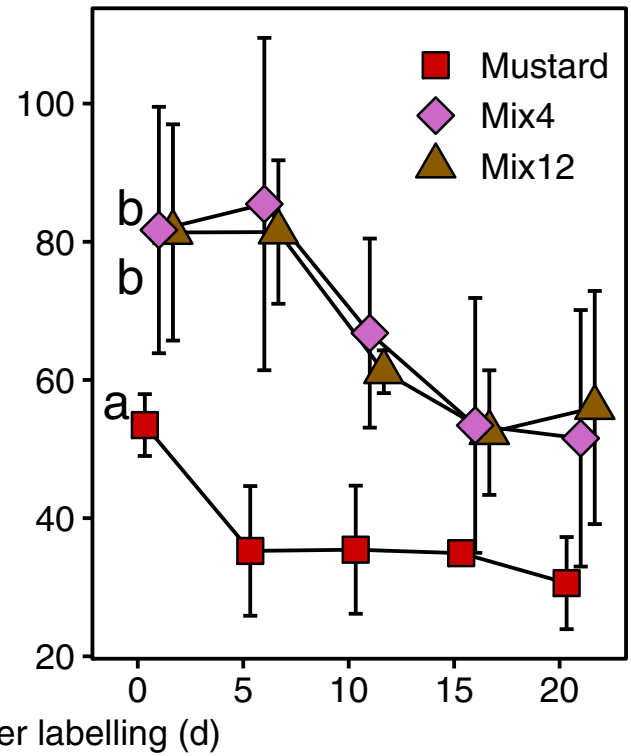


a)

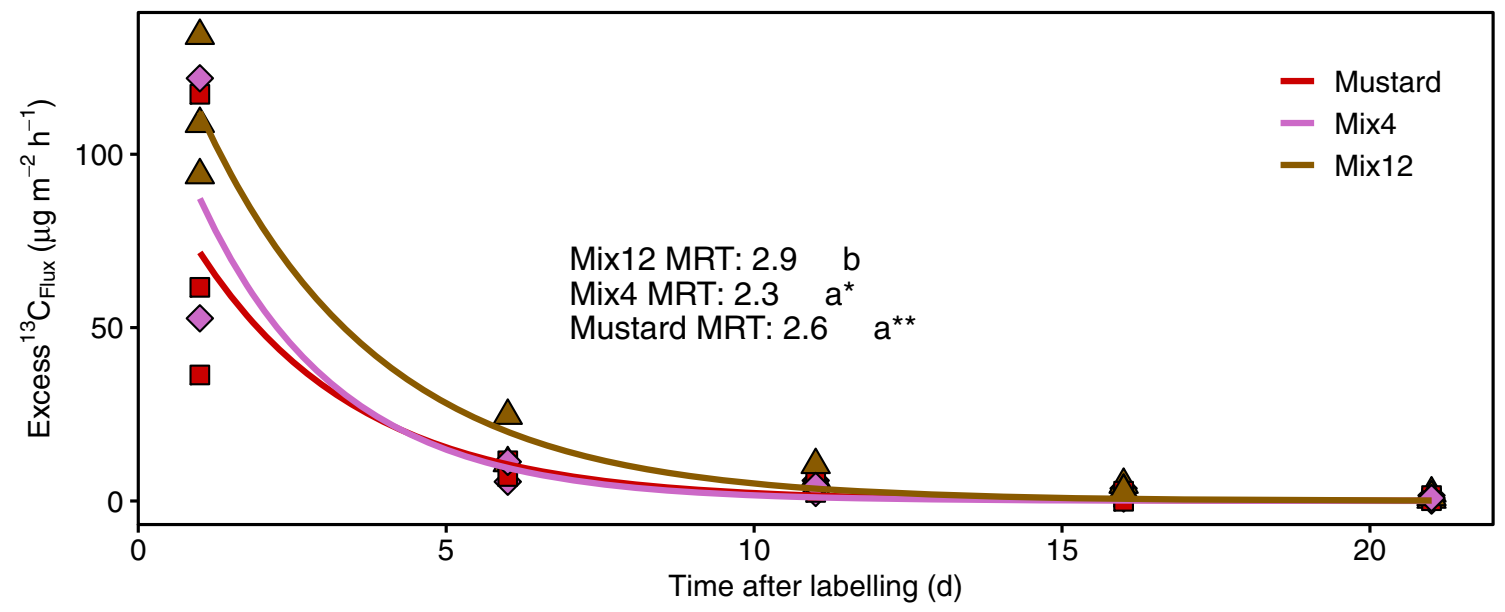

b)
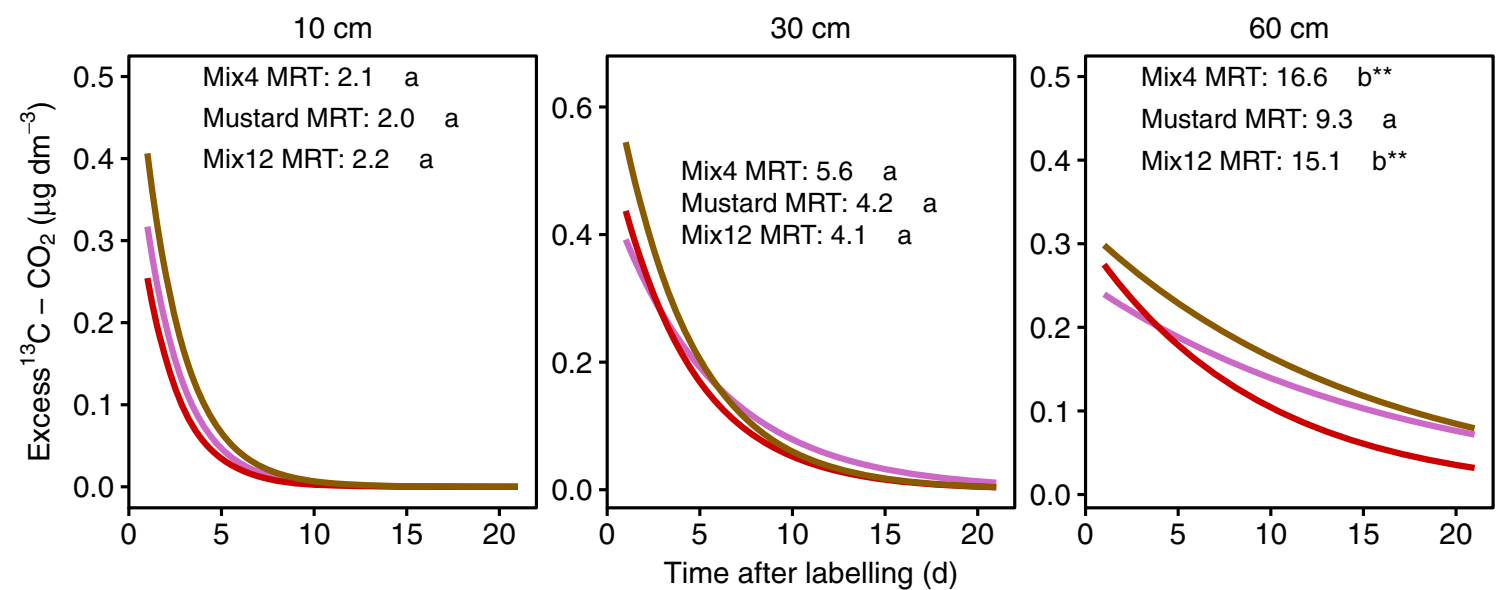

Fig. 3 Exponential fit of the excess ${ }^{13} \mathrm{C}$ in soil respiration after labelling. Symbols represent means $\pm \mathrm{SE}$; lowercase letters following the mean residence time (MRT in days) denote significant differences $(* p<0.05, * * p<0.01)$ between treatments

The mean residence time of ${ }^{13} \mathrm{C}$ in the $\mathrm{CO}_{2}$ efflux from soil monitored from the collars at the soil surface (Fig. 3a) was significantly longer in mix $12(2.9 \pm$ 0.5 days $)$ than in mix $4(2.3 \pm 1.3$ days $)$ and mustard $(2.6 \pm 1.5$ days $)$. The residence time at different soil depths was not different between the treatments at the 10 and $30 \mathrm{~cm}$ soil depths (Fig. 3b). A significantly longer MRT was found under the two mixed catch crops compared to that under mustard at the $60 \mathrm{~cm}$ sampling depth. The presence of roots at this soil depth was shown by Heuermann et al. (2019). These results show faster belowground $\mathrm{C}$ turnover in mustard and mix 12 and a higher $\mathrm{C}$ transfer rate towards the deeper rooting layer in mix 4 and mix 12 .

Significant correlation was found between the excess ${ }^{13} \mathrm{C}$ of various compartments (Fig. S6). The excess ${ }^{13} \mathrm{C}$ in roots was positively correlated to that in shoots, the bulk soil, $\mathrm{CO}_{2}$ efflux and various PLFA markers (total, fungi, gram negative bacteria, protozoa).

\section{Microbial C acquisition}

The total microbial PLFA biomass at $0-10 \mathrm{~cm}$ depth (Fig. 4 left facet) increased significantly $(p<0.05)$ in the order of fallow $\left(146.7 \pm 14.0 \mathrm{nmol} \mathrm{g}{ }^{-1}\right)$, mustard $(168.0 \pm$ $\left.16.3 \mathrm{nmol} \mathrm{g}^{-1}\right)$, mix $4\left(219.6 \pm 41.1 \mathrm{nmol} \mathrm{g}^{-1}\right)$ and mix12 $\left(309.7 \pm 50.3 \mu \mathrm{mol} \mathrm{g}^{-1}\right)$. In contrast, the total PLFAs were significantly lower at $20-30 \mathrm{~cm}$, but no differences were found among the treatments (Fig. 4 right facet). The fungal PLFA biomass increased significantly in the order of fallow $\left(9.6 \pm 1.2 \mu \mathrm{mol} \mathrm{g}^{-1}\right)$, mustard $\left(12.6 \pm 1.9 \mu \mathrm{mol} \mathrm{g}{ }^{-1}\right)$, mix 4 $\left(24.7 \pm 6.7 \mu \mathrm{mol} \mathrm{g}^{-1}\right)$ and mix $12\left(38.6 \pm 8.4 \mu \mathrm{mol} \mathrm{g}{ }^{-1}\right)$ but decreased at $20-30 \mathrm{~cm}$ depth by up to 5 times, with no differences among treatments (Fig. 4). The variability within the unspecified bacterial markers was too high to detect valid significant differences among the treatments (Fig. 4). The same was true for gram-positive and gram-negative bacterial PLFAs. Actinobacterial PLFAs in the $0-10 \mathrm{~cm}$ layer were similar for the fallow and mustard treatments and increased 

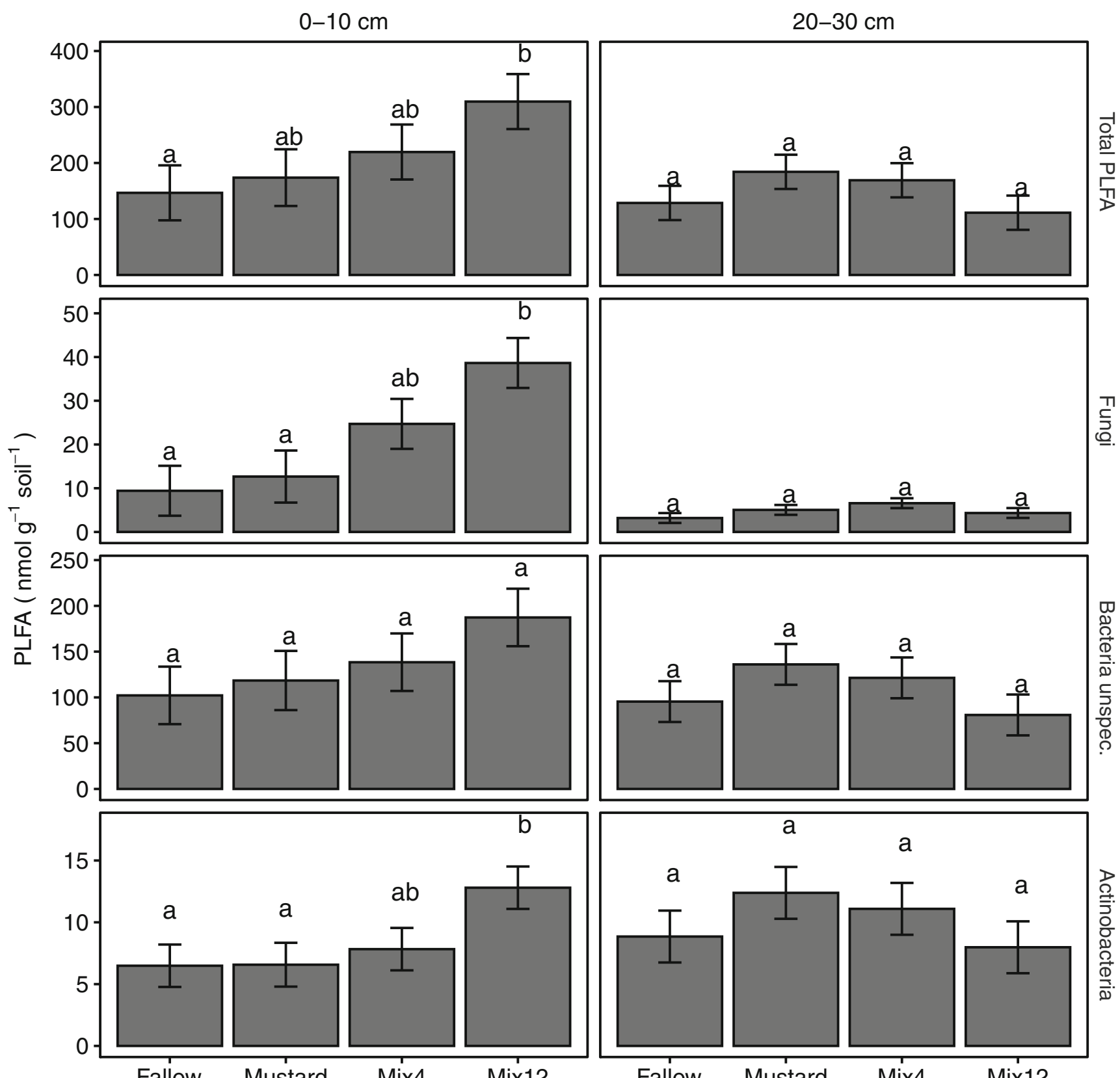

Fig. 4 Summarized functional grouped PLFAs over all time points. Bars represent least squared means \pm SE, and lowercase letters denote significant differences $(p<0.05)$ between treatments over all time intervals

significantly in mix 4 and mix 12 . The fungi to bacteria ratios at both soil depths were significantly higher in the mix 4 and mix 12 treatments than in the fallow and mustard treatments (Fig. 5). In the 20-30 cm soil layer, the fungi to bacteria ratios decreased by fivefold in all treatments. The PLFA biomass of individual microbial groups was summarized as PLFA stocks to $30 \mathrm{~cm}$ soil depth in Fig. S2. The PLFA stocks follow the statistic trends as in the $0-10 \mathrm{~cm}$ increment and indicated significant increase of the biomass with increasing catch crop diversity.
The transfer of $\mathrm{C}$ from the ${ }^{13} \mathrm{C}$ pulse in the total PLFAs and fungal PLFAs is shown in Fig. 6. On average, three times more excess ${ }^{13} \mathrm{C}$ was found in the total PLFAs for mix 12 compared to that for mustard (Fig. 6a left), while the mix 4 amount was between the mix 12 and mustard amounts. The drop in excess ${ }^{13} \mathrm{C}$ at day 11 followed a microbial biomass decrease after a 2-day period of low night temperatures and a subsequent warmer period. Although mustard and mix 4 tended to increase the excess ${ }^{13} \mathrm{C}$ towards the end of the experiment at the $20-30 \mathrm{~cm}$ soil depth, the variability among the treatments was very high, and the differences were not 


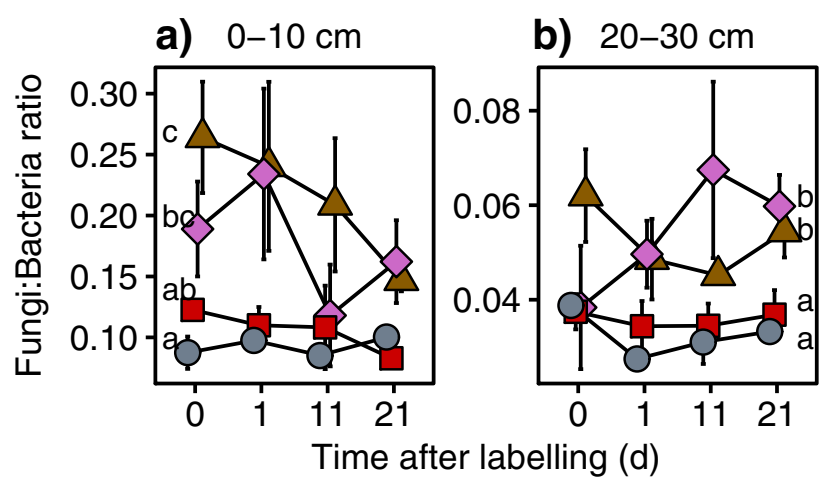

$\bigcirc$ Fallow $\square$ Mustard $\diamond \operatorname{Mix4} \triangle \operatorname{Mix} 12$

Fig. 5 Fungal to bacterial PLFA ratios at different sampling times after label application. Symbols represent means \pm SE; lowercase letters denote significant differences $(p<0.05)$ between treatments over all time intervals

statistically significant (Fig. 6a right). The ${ }^{13} \mathrm{C}$ excess in fungal PLFAs was significantly larger in mix 12 than in mustard, while that of mix 4 was between the values of the two treatments (Fig. 6b). The variability within the ${ }^{13} \mathrm{C}$ pulse of bacterial PLFAs after labelling caused large standard errors, and no differences were detected among the catch crop treatments.

The proportion of bacterial and fungal excess ${ }^{13} \mathrm{C}$ to the total PLFA excess ${ }^{13} \mathrm{C}$ was described as the relative abundance. Overall, the relative abundance of bacterial excess ${ }^{13} \mathrm{C}$ increased towards the end of the experiment (Fig. 7a), while the relative abundance of fungal PLFAs decreased (Fig. 7b). Up to three times more $\mathrm{C}$ was transferred to bacterial PLFAs in mustard compared to in mix 4 and mix 12 (Fig. 7a). The averaged relative abundance of fungal ${ }^{13} \mathrm{C}$ increased from 10 to $37 \%(0-10 \mathrm{~cm}$ depth) and from 5 to $25 \%(20-30 \mathrm{~cm}$ depth) in the order mustard, Mix 4 and mix 12 (Fig. 7b). The excess ${ }^{13} \mathrm{C}$ in fungal PLFAs was significantly correlated with the excess ${ }^{13} \mathrm{C}$ in plant roots, the bulk soil, unspecified bacteria, gram-positive bacteria, gram-negative bacteria and protozoa (Fig. S6). The excess ${ }^{13} \mathrm{C}$ bacterial PLFAs was positively correlated to that in fungal PLFAs but not to the excess ${ }^{13} \mathrm{C}$ in plant organs and the bulk soil. Significant correlations were also found between NEE and total, fungal, bacterial and actinobacterial PLFAs (Fig. S5a-c). These relationships demonstrated that as more $\mathrm{C}$ was taken up from the atmosphere, more microbial biomass $\mathrm{C}$ could be found in the upper soil layer.

\section{Discussion}

\section{NEE is linked to plant diversity}

Croplands can be sources or sinks of $\mathrm{C}$ and the fluxes between cropland and the atmosphere depend on the farming practices and the entire crop rotation. The introduction of mustard as catch crop resulted in a negative NEE and increases ecosystem uptake of $\mathrm{C}$ at the rotation scale (Lehuger et al. 2010). The NEE in our study showed a remarkably strong negative gradient from mustard to mix 4 to mix 12 (Fig. 1), which suggested higher photosynthetic $\mathrm{CO}_{2}$-C fixation rates with increasing catch crop diversity. In the following, we discuss these findings from several perspectives.

The higher efficiency of atmospheric $\mathrm{C}$ fixation in diversified catch crops may have resulted from the advantage of vertical plant stratification. Total shoot biomass varied only marginally between catch crop treatments and, therefore, was not a good predictor for NEE. Mustard grows fast and builds up long stalks with productive leaves mainly in the upper plant parts, with no understory. In more diverse catch crop mixtures, vertical layers grow according to the different plant heights. Unfortunately, we did not separate leaves and stalks in this experiment. We were, however, able to gain some information from a greenhouse experiment with the same treatments (Fig. S8). Mix 12 resulted in a higher percentage of photosynthetically active leaves than stalks (leaf to stalk ratio of $1.63 \pm$ 0.37 ), while in mix 4 and mustard, a high percentage of stalk biomass was produced (leaf to stalk ratios of $0.99 \pm 0.11$ and $0.79 \pm 0.03)$. When applying these data to our field experiment, we found a slight positive trend with leaf biomass (Fig. S9a) and a strong negative correlation with stalk biomass (Fig. S9b). These relationships suggest that NEE depends on shoot biomass differentiation and that a higher proportion of leaf than stalk biomass results in higher photosynthetic $\mathrm{CO}_{2}-\mathrm{C}$ fixation rates. In future studies, the leaf area index (LAI) could probably provide more detailed information because leaf area expansion has been shown to be very important for the photosynthetic performance of catch crops during the late growing season (Vos and van der Putten 1997).

The photosynthetic capacity of plants is regulated to a certain extent by external nutrients, particularly $\mathrm{N}$ availability (Kumar et al. 2002). The mineral $\mathrm{N}$ stocks up to $0.9 \mathrm{~m}$ soil depth during the experiment were not different between the catch crops $\left(24.4 \pm 1.4 \mathrm{~kg} \mathrm{ha}^{-1}\right)$, and all catch crops equally depleted the soil $\mathrm{N}$ pool, by $90.1 \pm 10.9 \mathrm{~kg} \mathrm{ha}^{-1}$ on average (Table S1). Therefore, we did not expect that NEE would be affected by $\mathrm{N}$ availability. However, since we cannot rule out $\mathrm{N}$ transfer from legumes in the mixtures (Faget et al. 2013), positive impacts on photosynthetic activity might be possible. Such synergistic effects between plants but also between plants and microorganisms could explain why individual plants in mixtures are more efficient at $\mathrm{C}$ assimilation (Fig. S7) than pure stands.

Parts of the results might also have been affected by the phenological stage of plants. Some of the plants, particularly mustard and camelina, started to transition into the generative stage on the labelling day. Over the course of the experiment, mustard and camelina went into their flowering stages, and approximately 


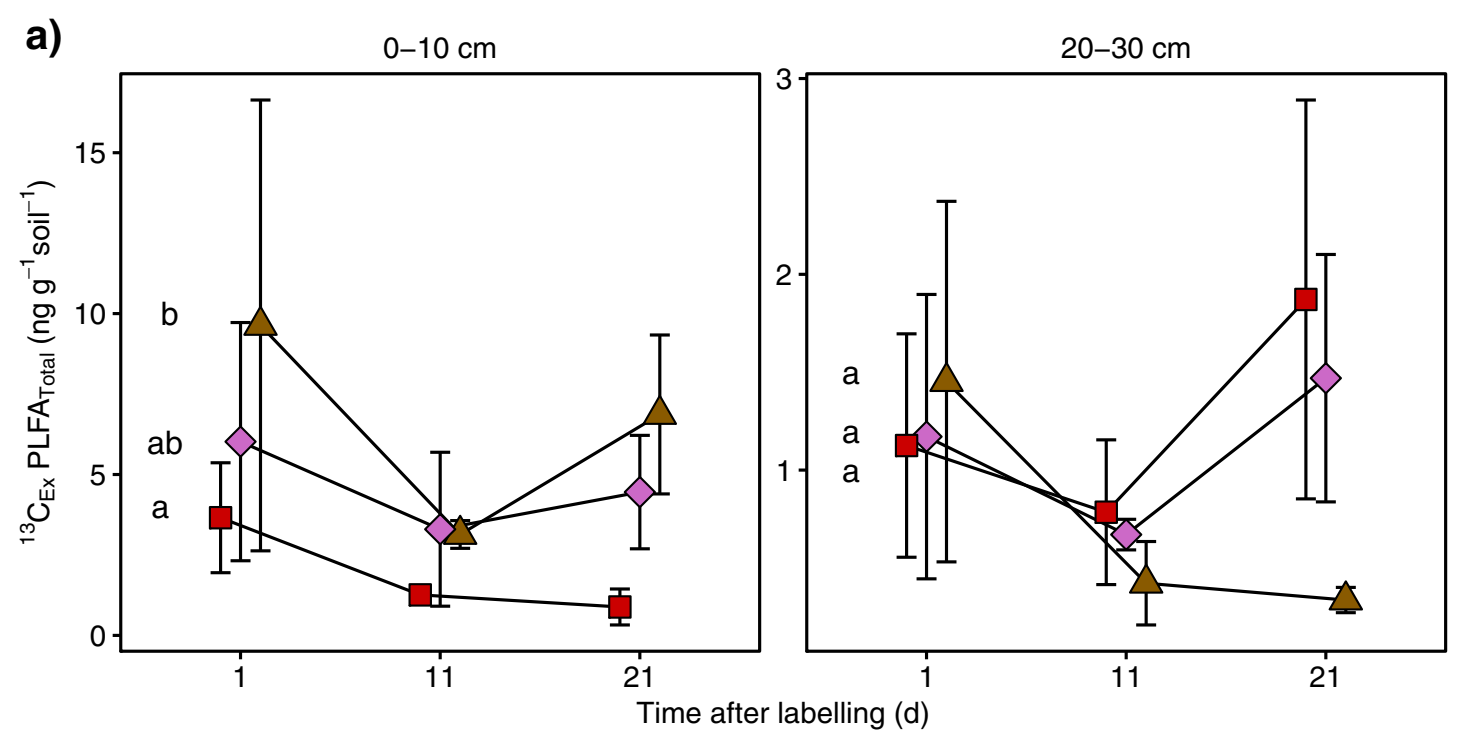

b)
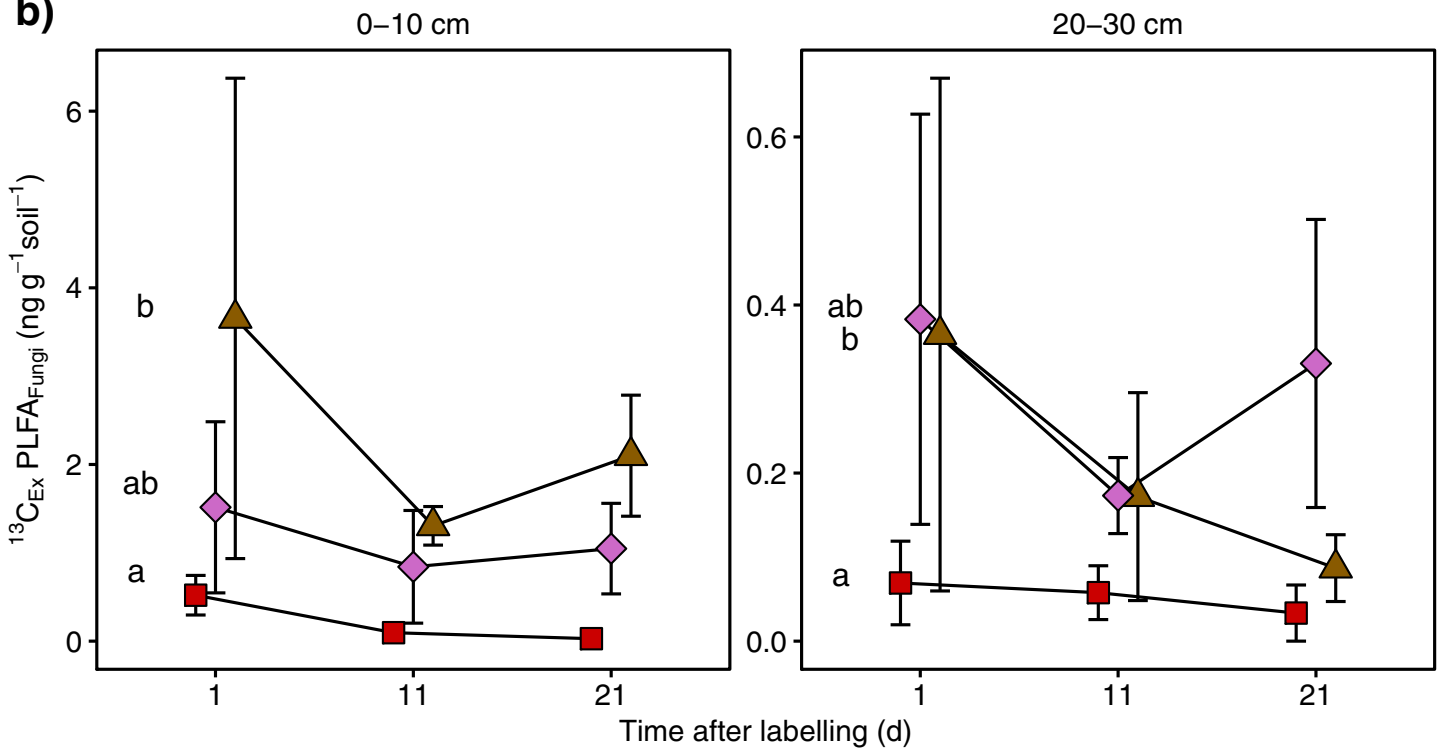

Mustard

$\operatorname{Mix} 4 \triangle \operatorname{Mix} 12$

Fig. 6 Excess ${ }^{13} \mathrm{C}\left({ }^{13} \mathrm{C}_{\mathrm{Ex}}\right)$ PLFAs of a total PLFAs and $\mathbf{b}$ fungal PLFAs. Symbols represent means $\pm \mathrm{SE}$; lowercase letters denote significant differences $(p<0.05)$ between treatments over all time intervals (time was as incorporated as random effects in LMMs)

$40 \%$ of the main raceme was open at the final harvest. When they flower, plants reduce root exudation, and root turnover becomes the dominant process of rhizodeposition in soil (Pausch and Kuzyakov 2018). In maturing root zones, epidermal cells already start to senesce, the concentration of easily decomposable root exudates decreases, and microbial activity and growth rates slow down (Marschner 2012). Nevertheless, the photosynthetic activity of the plant was not expected to be negatively affected by the start of flowering. For Brassica napus L.; for example, it was shown that the leaf area index and photosynthetic $\mathrm{CO}_{2}$ assimilation rate peaked at the start of flowering (Gammelvind et al. 1996). Therefore, the finding of about three times higher $\mathrm{C}$ uptake efficiency per plant in catch crop mixtures (Fig. S7) demonstrated the higher efficiency of photosynthetic C uptake when plants were grown in mixtures. Furthermore, the time of contributing root exudates to the rhizosphere is shorter for earlyflowering plants than for late-flowering plants. Consequently, even if root exudation rates in the early stages of plant development are comparable between early- and late-flowering catch crops, a longer vegetative stage will result in a higher total quantity of root exudates to the soil.

Overall, the results demonstrate the importance of continuous plant cover instead of fallow soil for the improvement of $\mathrm{C}$ cycling in agroecosystems. All catch crops showed significant net $\mathrm{CO}_{2}-\mathrm{C}$ uptake from the atmosphere, while constant loss of $\mathrm{C}$ occurred from heterotroph respiration in the fallow. 

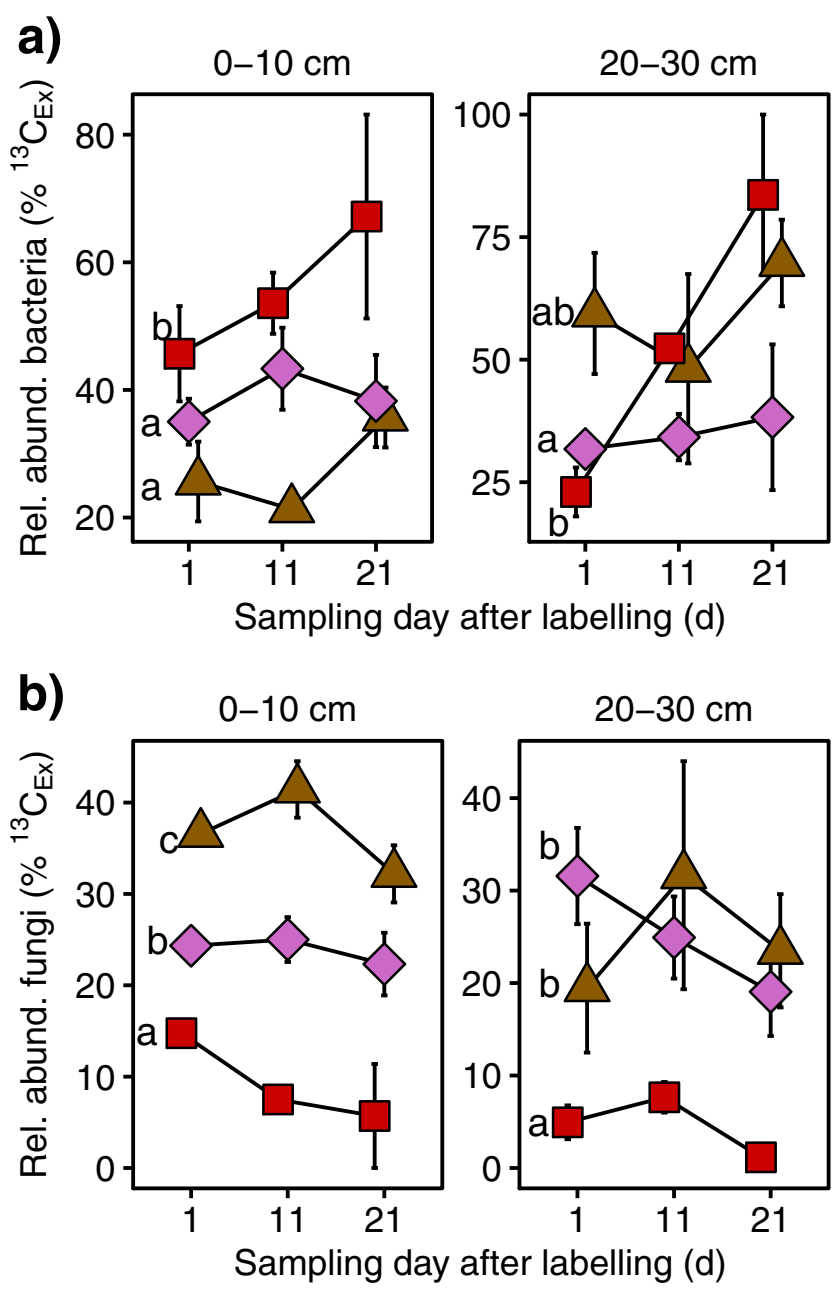

\section{Mustard $\diamond \operatorname{Mix4} \triangle \operatorname{Mix} 12$}

Fig. 7 Proportion of bacterial and fungal markers to the total PLFA excess ${ }^{13} \mathrm{C}$ presented as relative abundance $(\%)$. This measure is calculated by setting the amount of the recovered ${ }^{13} \mathrm{C}$ to $100 \%$ and calculating the percentage of the microbial groups thereof. The symbols represent means $\pm \mathrm{SE}$; lowercase letters denote significant differences $(p<0.05)$ between treatments over all time intervals (time was as incorporated as random effects in LMMs)

The efficiency of atmospheric $\mathrm{C}$ uptake by cover crops can be improved by increasing their diversity. We demonstrated that the main effect of this improvement was achieved through the vertical stratification of the aboveground biomass and the greater proportion of photosynthetically active leaves. However, the performance of individual plants might also increase when catch crops are grown in mixtures.

\section{Belowground C allocation increased with catch crop diversity}

The majority of the assimilated C remained in shoots (Fig. S3) to be used for respiration and biomass production (Pausch and Kuzyakov 2018). The different $\mathrm{CO}_{2}$-C uptake rates among the catch crops were mirrored in the excess ${ }^{13} \mathrm{C}$ in roots and shoots (Fig. 2). Although excess ${ }^{13} \mathrm{C}$ was similar in both mixed catch crops, a higher $\mathrm{C}$ transfer rate towards the roots was only detected for mix 12 . In a recent review, the maximum allocation rate from shoots to roots was found within the first day after label application (Pausch and Kuzyakov 2018). The authors generalized the $\mathrm{C}$ partitioning from a broad range of crop labelling experiments. They estimated that $79 \%$ of the assimilated $\mathrm{C}$ remains aboveground, while $21 \%$ is allocated belowground in different compartments. In our study, we recovered only $10 \%$ in belowground compartments $24 \mathrm{~h}$ after label application (Fig. S3). Most likely, the root biomass was not properly recovered with our method. Compared to recently published data from our study site, we underestimated the root biomass by a factor of 10 compared to that estimated by a qPCR-based method (Heuermann et al. 2019). Nonetheless, not only the absolute amount of recovered $\mathrm{C}$ but also the percentage of recovered root-, microbial- and respired- ${ }^{13} \mathrm{C}$ were higher for mix 12 than for mustard and mix 4. The recovered $\mathrm{C}$ in $\mathrm{CO}_{2}$ efflux directly refers to the $\mathrm{C}$ fraction that was respired by roots and rhizodeposits that were released by plants and mineralized by the rhizosphere microbiome. These findings illustrate higher rhizodeposition under mix 12 and faster $\mathrm{C}$ mineralization.

Despite the enhanced ${ }^{13} \mathrm{C}$ in the $\mathrm{CO}_{2}$ efflux from the mix 12 soil, its MRT was longer compared to those of mustard and mix 4 and indicated a longer turnover rate for recently assimilated $\mathrm{C}$ in soil (Fig. 3a). Particularly in the 60-70 $\mathrm{cm}$ soil layer, prolonged $\mathrm{C}$ retention was found (Fig. 3b). Similar to aboveground stratification, plants with different root performances are able to explore different rooting depths. The tap roots of radish, for example, can develop rather deep rooting systems with high root intensities up to $2.5 \mathrm{~m}$ soil depth (ThorupKristensen 2006). Egyptian clover, on the other hand, develops its major root systems in the upper $30 \mathrm{~cm}$, while field pea explores an intermediate soil depth of 30-90 cm. Rooting depth was related to higher $\mathrm{C}$ input towards the subsoil (Lynch and Wojciechowski 2015) despite the results were not always consistent (Poffenbarger et al. 2020). Thus, the mix of shallow, medium and deep rooting species in mix 12 may not only occupy a larger rooting volume in the soil more efficiently (Heuermann et al. 2019) but also allocate more $C$ towards the deeper rooting zone.

Higher rhizosphere $\mathrm{C}$ inputs, particularly of low molecular weight root exudates, can also result in a rhizosphere priming effect from native soil C (Kuzyakov 2010). Rhizosphere priming can differ considerably among plant species and their phenological stages (Cheng et al. 2003; Zhu et al. 2014). We found, however, very similar $\mathrm{CO}_{2}-\mathrm{C}$ respiration rates from the soils of the different catch crop treatments (Fig. S10). Therefore, the higher total belowground transfer rate of mix 
12 most likely did not result in a greater soil OC mineralisation. Furthermore, the ratio of recovered total belowground ${ }^{13} \mathrm{C}$ to soil efflux ${ }^{13} \mathrm{C}$ was similar for mustard (2.9 $\pm 0.8)$, mix $4(2.7 \pm 0.9)$ and mix $12(2.9 \pm 1.1)$. These data suggest that all catch crops facilitate net rhizodeposition and that almost 3 times more recently assimilated $\mathrm{C}$ remained in the belowground compartments than was respired to the atmosphere.

\section{Soil microbial groups}

Recent studies have shown that catch crops have positive effects on microbial abundance, activity and diversity compared to those of fallow soil (Finney et al. 2017; Kim et al. 2020). The soil microbiome is thereby affected by several interlinked pathways. First, by extending the period of vegetation cover, catch crops support microorganisms that depend on rhizodeposition and plant symbiosis (Schmidt et al. 2019). Second, by the decay of root and shoot litter fragments, catch crops encourage soil microbial functional diversity (Nivelle et al. 2016) and saprotrophic communities (Nevins et al. 2018; Barel et al. 2019). Third, catch crops can actively alter the rhizosphere community composition by producing allelopathic compounds in the rhizosphere, such as those of Brassicaceae or sorghum (Lankau et al. 2011; Chaparro et al. 2012; Sarr et al. 2020).

Our results support these previous findings and show that all catch crops affected the biomass of soil microbial groups compared to that in fallow soil (Fig. S2). We found a direct relationship between NEE and various soil microbial PLFA markers (Fig. S5). These data suggest that the soil microbiome is controlled to a certain extent by the capacity of plants for atmospheric $\mathrm{C}$ uptake. Further, catch crop treatments were positively related to microbial biomass increase, which suggests that plant species richness is a driver of the soil microbiome. Increasing the plant diversity in catch crop treatments can therefore be useful for optimizing the $\mathrm{C}$ flow from the atmosphere-plant system towards the soil microbiome. These higher transfer rates of recently assimilated $\mathrm{C}$ towards soil microbial groups were reflected by the higher excess ${ }^{13} \mathrm{C}$, particularly at the $0-10 \mathrm{~cm}$ soil depth (Fig. 6).

The actinobacterial and fungal communities benefit the most from diversified catch crop management. In the soil environment, actinobacteria play an important role in litter decomposition, soil OM formation, nutrient cycling and the degradation of complex polymeric substances such as organic and inorganic pollutants (Alvarez et al. 2017). Due to their partly filamentous morphology (particularly the order Actinomycetales), the high Actinobacteria colonization in the interior of micro aggregates was linked to positive impacts on soil structure and aggregate formation (Mummey et al. 2006). Fungal biomass as well as fungi to bacteria ratios increased significantly (Figs. 4, 5 and S1), suggesting that fungal biomass increased from 10 to $30 \%(0-10 \mathrm{~cm})$ and 4 to $7 \%$ $(20-30 \mathrm{~cm})$ with increasing catch crop diversity. The enhanced fungal biomass corresponded to higher recovery rates of recently assimilated ${ }^{13} \mathrm{C}$ in fungal PLFAs (Fig. 6). Only between 5 and $10 \%$ of the total PLFA-recovered ${ }^{13} \mathrm{C}$ was found in fungi when mustard was grown in pure stands, while the vast majority was transferred towards the bacterial communities (Fig. 7). In contrast, with increasing plant diversity, fungi receive between 25 and $37 \%$ of the PLFA-recovered ${ }^{13} \mathrm{C}$, and the proportion of bacterial receivers decreases. The excess ${ }^{13} \mathrm{C}$ in fungi was positively correlated with the excess ${ }^{13} \mathrm{C}$ in plant roots, shoots and the bulk soil (Fig. S6) which suggested that the higher $\mathrm{C}$ transfer rates towards the rhizosphere increased the fungal biomass. These findings fit previous observations of increasing fungal biomass with plant diversity (Eisenhauer et al. 2017). In particular, endophytic symbiotrophic fungi, such as mycorrhizae (Finney et al. 2017; Schmidt et al. 2019) as well as saprotrophic fungi, may profit from the higher root biomass and rhizodeposition of diversified catch crops (Eisenhauer et al. 2017). Further, the correlation of fungal excess ${ }^{13} \mathrm{C}$ to that of bacterial markers suggested fungi as a mediators for distributing recently assimilated $\mathrm{C}$ towards the soil bacterial community. In fact, no correlation between bacterial PLFA and excess ${ }^{13} \mathrm{C}$ in plant organs was found (Fig. S6). But also protozoa that feed on fungal products might profit from the higher fungal $\mathrm{C}$ input.

Fungi are crucial drivers for nutrient cycling, OM decomposition and soil structure maintenance in arable soils but are susceptible to management practices (Schmidt et al. 2019). Intensive soil management and OM degradation have reduced the biomass and functional diversity of soil fungi, thereby confining fungi-mediated ecosystem services in agroecosystems (Six et al. 2006; Thiele-Bruhn et al. 2012). Our data demonstrated that it is possible to stimulate fungal biomass in arable soils by increasing the rhizosphere $\mathrm{C}$ input in catch crop rotations, even under conventional farming practices. Elevated root exudation rates were shown to increase fungal biomass and shift the fungal-to-bacterial biomass ratio (Eisenhauer et al. 2017) and have been linked to higher biotic macroaggregation and $\mathrm{C}$ sink strength in the rhizosphere (Bender et al. 2016; Baumert et al. 2018). Therefore, we conclude that managing the plant diversity in crop rotations could bring back some of the downgraded services provided by the fungal community.

Taken together, the higher NEE, most likely in combination with the longer vegetative stage of catch crops, increased the belowground transfer rates of recently fixed photoassimilates. The higher rhizosphere $\mathrm{C}$ input stimulated the growth and activity of the soil microbial groups and particularly supported the fungal and actinobacterial community. We conclude that catch crops exert control on the active microbial groups by affecting the composition of plant communities. Higher microbial $\mathrm{C}$ is also 
correlated with higher biomass N. Thus, translating postharvest nutrients into active microbial biomass could also prevent leaching losses and stimulate mineralization patterns. Increasing rhizodeposition and $\mathrm{C}$ transfer towards the soil microbiome favours soil $\mathrm{C}$ storage because direct inputs to the soil matrix allow a higher degree of physicochemical stabilization (Soussana and Lemaire 2014). The design of sustainable agroecosystems requires the movement of current agricultural practices and the diversification of catch crops and green manures could be one piece of the puzzle.

\section{Conclusion}

This study linked catch crop plant diversity to short-term rhizosphere $\mathrm{C}$ inputs and their residence time in soil. The net atmospheric $\mathrm{C}$ uptake by catch crops was shown to increase significantly with catch crop diversity, and at the same time, the transport of photoassimilates towards the roots and the rhizosphere increased. We conclude that the major driver for the higher belowground $\mathrm{C}$ transfer rates under diverse catch crops originates from the higher $\mathrm{CO}_{2}$ fixation rate of the aboveground biomass and the improved translocation of $\mathrm{C}$ to different belowground compartments and their residence time therein. These compartments include C-respiring roots, the transfer of photoassimilates to microbial plant symbionts or rootassociated microbes and their subsequent respiration. The soil microbial groups under diverse catch crops responded to the higher rhizosphere $\mathrm{C}$ input with the shift towards a fungal dominated community and increasing biomass, particularly in the fungal and actinobacterial groups in the upper $0-10 \mathrm{~cm}$ soil depth. The increased residence time for recently assimilated $\mathrm{C}$ compounds in the soil was presumably due to the longer retention time in both roots and microbial biomass. Particularly, the latter finding appeared important for sustainable farming practices, since microbial products have been proposed as ways to increase slow-cycling organic matter, $\mathrm{C}$ sequestration and nutrient retention in soils. As microorganisms serve as a catalyst of nutrient cycling, the stimulation of microbial groups will most likely directly affect the nutrient fluxes in soil. Specially designed catch crop mixtures could be applied as tools for the targeted management of soil biota to deliver specific desired functions and enhance overall ecosystem service delivery. Further research is required on the impact of plant diversity in agroecosystems on microbial community composition and the associated impacts on soil properties. It should also cover the role of the microbial community as a source or sink for nutrients in arable soils.
Acknowledgments This work is part of the BonaRes project (Soil as a Sustainable Resource for the Bioeconomy) CATCHY (Catch-cropping as an agrarian tool for continuing soil health and yield increase).

Funding information Open Access funding provided by Projekt DEAL. The authors received funding from the German Federal Ministry of Education and Research (BMBF), project number 031A559C.

Data availability After acceptance, the datasets generated during the current study will be freely available from the BonaRes Data Centre (https:// datenzentrum.bonares.de/research-data.php).

\section{Compliance with ethical standards}

Conflict of interest The authors declare that they have no conflict of interest.

Open Access This article is licensed under a Creative Commons Attribution 4.0 International License, which permits use, sharing, adaptation, distribution and reproduction in any medium or format, as long as you give appropriate credit to the original author(s) and the source, provide a link to the Creative Commons licence, and indicate if changes were made. The images or other third party material in this article are included in the article's Creative Commons licence, unless indicated otherwise in a credit line to the material. If material is not included in the article's Creative Commons licence and your intended use is not permitted by statutory regulation or exceeds the permitted use, you will need to obtain permission directly from the copyright holder. To view a copy of this licence, visit http://creativecommons.org/licenses/by/4.0/.

\section{References}

Abdalla M, Hastings A, Cheng K, Yue Q, Chadwick D, Espenberg M, Truu J, Rees RM, Smith P (2019) A critical review of the impacts of cover crops on nitrogen leaching, net greenhouse gas balance and crop productivity. Glob Chang Biol 25:2530-2543. https://doi.org/ $10.1111 / \mathrm{gcb} .14644$

Ahmed MA, Banfield CC, Sanaullah M, Gunina A, Dippold MA (2018) Utilisation of mucilage $\mathrm{C}$ by microbial communities under drought. Biol Fertil Soils 54:83-94. https://doi.org/10.1007/s00374-0171237-6

Alvarez A, Saez JM, Davila Costa JS, Colin VL, Fuentes MS, Cuozzo SA, Benimeli CS, Polti MA, Amoroso MJ (2017) Actinobacteria: current research and perspectives for bioremediation of pesticides and heavy metals. Chemosphere 166:41-62. https://doi.org/10. 1016/j.chemosphere.2016.09.070

Barel JM, Kuyper TW, Paul J, de Boer W, Cornelissen JH, De Deyn GB (2019) Winter cover crop legacy effects on litter decomposition act through litter quality and microbial community changes. J Appl Ecol 56:132-143. https://doi.org/10.1111/1365-2664.13261

Baumert VL, Vasilyeva NA, Vladimirov AA, Meier IC, Kögel-Knabner I, Mueller CW (2018) Root exudates induce soil macroaggregation facilitated by fungi in subsoil. Front Environ Sci:6. https://doi.org/ 10.3389 /fenvs. 2018.00140

Bender SF, Wagg C, van der Heijden MGA (2016) An underground revolution: biodiversity and soil ecological engineering for agricultural sustainability. Trends Ecol Evol 31:440-452. https://doi.org/ 10.1016/j.tree.2016.02.016

Bischoff N, Mikutta R, Shibistova O, Puzanov A, Reichert E, Silanteva M, Grebennikova A, Schaarschmidt F, Heinicke S, Guggenberger G (2016) Land-use change under different climatic conditions: 
consequences for organic matter and microbial communities in Siberian steppe soils. Agric Ecosyst Environ 235:253-264. https:// doi.org/10.1016/j.agee.2016.10.022

Chaparro JM, Sheflin AM, Manter DK, Vivanco JM (2012) Manipulating the soil microbiome to increase soil health and plant fertility. Biol Fertil Soils 48:489-499. https://doi.org/10.1007/ s00374-012-0691-4

Cheng W, Johnson DW, Fu S (2003) Rhizosphere effects on decomposition. Soil Sci Soc Am J 67:1418-1427. https://doi.org/10.2136/ sssaj2003.1418

Couëdel A, Alletto L, Tribouillois H, Justes É (2018) Cover crop cruciferlegume mixtures provide effective nitrate catch crop and nitrogen green manure ecosystem services. Agric Ecosyst Environ 254:50 59. https://doi.org/10.1016/j.agee.2017.11.017

Eisenhauer N, Lanoue A, Strecker T, Scheu S, Steinauer K, Thakur MP, Mommer L (2017) Root biomass and exudates link plant diversity with soil bacterial and fungal biomass. Sci Rep 7:1-8. https://doi. org/10.1038/srep44641

Faget M, Nagel KA, Walter A, Herrera JM, Jahnke S, Schurr U, Temperton VM (2013) Root-root interactions: extending our perspective to be more inclusive of the range of theories in ecology and agriculture using in-vivo analyses. Ann Bot 112:253-266. https:// doi.org/10.1093/aob/mcs296

Finney D, Buyer J, Kaye JP (2017) Living cover crops have immediate impacts on soil microbial community structure and function. J Soil Water Conserv 72:361-373. https://doi.org/10.2489/jswc.72.4.361

Finney DM, White CM, Kaye JP (2016) Biomass production and carbon/ nitrogen ratio influence ecosystem services from cover crop mixtures. Agron J 108:39-52. https://doi.org/10.2134/agronj15.0182

Gammelvind LH, Schjoerring JK, Mogensen VO, Jensen CR, Bock JGH (1996) Photosynthesis in leaves and siliques of winter oilseed rape (Brassica napus L.). Plant Soil 186:227-236. https://doi.org/10. 1007/BF02415518

Gunina A, Dippold MA, Glaser B, Kuzyakov Y (2014) Fate of low molecular weight organic substances in an arable soil: from microbial uptake to utilisation and stabilisation. Soil Biol Biochem 77: 304-313. https://doi.org/10.1016/j.soilbio.2014.06.029

Heuermann D, Gentsch N, Boy J, Schweneker D, Feuerstein U, Groß J, Bauer B, Guggenberger G, von Wirén N (2019) Interspecific competition among catch crops modifies vertical root biomass distribution and nitrate scavenging in soils. Sci Rep 9:1-11. https://doi.org/ 10.1038/s41598-019-48060-0

IUSS Working Group WRB (2014) World Reference Base for Soil Resources 2014. International soil classification system for naming soils and creating legends for soil maps. Food and Agriculture Organization, Rome

Jones DL, Nguyen C, Finlay RD (2009) Carbon flow in the rhizosphere: carbon trading at the soil-root interface. Plant Soil 321:5-33. https:// doi.org/10.1007/s11104-009-9925-0

Kanders MJ, Berendonk C, Fritz C, Watson C, Wichern F (2017) Catch crops store more nitrogen below-ground when considering Rhizodeposits. Plant Soil 417:287-299. https://doi.org/10.1007/ s11104-017-3259-0

Kaye JP, Quemada M (2017) Using cover crops to mitigate and adapt to climate change. A review. Agron Sustain Dev 37:4. https://doi.org/ 10.1007/s13593-016-0410-x

Kim N, Zabaloy MC, Guan K, Villamil MB (2020) Do cover crops benefit soil microbiome? A meta-analysis of current research. Soil Biol Biochem 142:107701. https://doi.org/10.1016/j.soilbio.2019. 107701

Kirkegaard JA, Sarwar M (1998) Biofumigation potential of brassicas. Plant Soil 201:71-89. https://doi.org/10.1023/A:1004364713152

Kumar PA, Parry MAJ, Mitchell RAC, Ahmad A, Abrol YP (2002) Photosynthesis and nitrogen-use efficiency. In: Foyer $\mathrm{CH}$, Noctor $\mathrm{G}$ (eds) Photosynthetic nitrogen assimilation and associated carbon and respiratory metabolism. Springer, Dordrecht, pp 23-34
Kumar R, Pandey S, Pandey A (2006) Plant roots and carbon sequestration. Curr Sci 91:885-890

Kuzyakov Y (2010) Priming effects: interactions between living and dead organic matter. Soil Biol Biochem 42:1363-1371. https://doi.org/ 10.1016/j.soilbio.2010.04.003

Kuzyakov Y, Gavrichkova O (2010) REVIEW: time lag between photosynthesis and carbon dioxide efflux from soil: a review of mechanisms and controls. Glob Chang Biol 16:3386-3406. https://doi.org/ 10.1111/j.1365-2486.2010.02179.x

Lankau RA, Wheeler E, Bennett AE, Strauss SY (2011) Plant-soil feedbacks contribute to an intransitive competitive network that promotes both genetic and species diversity. J Ecol 99:176-185. https://doi.org/10.1111/j.1365-2745.2010.01736.x

Lehuger S, Gabrielle B, Cellier P, Loubet B, Roche R, Béziat P, Ceschia E, Wattenbach M (2010) Predicting the net carbon exchanges of crop rotations in Europe with an agro-ecosystem model. Agric Ecosyst Environ 139:384-395. https://doi.org/10.1016/j.agee.2010. 06.011

Lynch JP, Wojciechowski T (2015) Opportunities and challenges in the subsoil: pathways to deeper rooted crops. J Exp Bot 66:2199-2210. https://doi.org/10.1093/jxb/eru508

Marschner P (2012) Chapter 15 - Rhizosphere biology. In: Marschner P (ed) Marschner's mineral nutrition of higher plants (third edition). Academic Press, San Diego, CA, pp 369-388

Mazzoncini M, Sapkota TB, Bàrberi P, Antichi D, Risaliti R (2011) Long-term effect of tillage, nitrogen fertilization and cover crops on soil organic carbon and total nitrogen content. Soil Tillage Res 114:165-174. https://doi.org/10.1016/j.still.2011.05.001

Mummey D, Holben W, Six J, Stahl P (2006) Spatial stratification of soil bacterial populations in aggregates of diverse soils. Microb Ecol 51: 404-411. https://doi.org/10.1007/s00248-006-9020-5

Nevins CJ, Nakatsu C, Armstrong S (2018) Characterization of microbial community response to cover crop residue decomposition. Soil Biol Biochem 127:39-49. https://doi.org/10.1016/j.soilbio.2018.09.015

Nivelle E, Verzeaux J, Habbib H, Kuzyakov Y, Decocq G, Roger D, Lacoux J, Duclercq J, Spicher F, Nava-Saucedo J-E (2016) Functional response of soil microbial communities to tillage, cover crops and nitrogen fertilization. Appl Soil Ecol 108:147-155. https://doi.org/10.1016/j.apsoil.2016.08.004

Pataki DE, Ehleringer JR, Flanagan LB, Yakir D, Bowling DR, Still CJ, Buchmann N, Kaplan JO, Berry JA (2003) The application and interpretation of keeling plots in terrestrial carbon cycle research. Glob Biogeochem Cycles 17:1022. https://doi.org/10.1029/ 2001GB001850

Paul EA (ed) (2007) Soil microbiology, ecology, and biochemistry, 3rd edn. Elsevier Academic Press, San Diego, CA

Pausch J, Kuzyakov Y (2018) Carbon input by roots into the soil: quantification of rhizodeposition from root to ecosystem scale. Glob Chang Biol 24:1-12. https://doi.org/10.1111/gcb.13850

Poffenbarger HJ, Olk DC, Cambardella C, Kersey J, Liebman M, Mallarino A, Six J, Castellano MJ (2020) Whole-profile soil organic matter content, composition, and stability under cropping systems that differ in belowground inputs. Agric Ecosyst Environ 291: 106810. https://doi.org/10.1016/j.agee.2019.106810

R Core Team (2017) R: a language and environment for statistical computing. R Foundation for Statistical Computing, Vienna

Reddy PP (2013) Biofumigation. In: Reddy PP (ed) Recent advances in crop protection. Springer, New Delhi, pp 37-60

Sarr PS, Ando Y, Nakamura S, Deshpande S, Subbarao GV (2020) Sorgoleone release from sorghum roots shapes the composition of nitrifying populations, total bacteria, and archaea and determines the level of nitrification. Biol Fertil Soils 56:145-166. https://doi.org/ 10.1007/s00374-019-01405-3

Schmidt R, Mitchell J, Scow K (2019) Cover cropping and no-till increase diversity and symbiotroph:saprotroph ratios of soil fungal 
communities. Soil Biol Biochem 129:99-109. https://doi.org/10. 1016/j.soilbio.2018.11.010

Six J, Frey SD, Thiet RK, Batten KM (2006) Bacterial and fungal contributions to carbon sequestration in agroecosystems. Soil Sci Soc Am J 70:555-569. https://doi.org/10.2136/sssaj2004.0347

Soussana J-F, Lemaire G (2014) Coupling carbon and nitrogen cycles for environmentally sustainable intensification of grasslands and croplivestock systems. Agric Ecosyst Environ 190:9-17. https://doi.org/ 10.1016/j.agee.2013.10.012

Thiele-Bruhn S, Bloem J, de Vries FT, Kalbitz K, Wagg C (2012) Linking soil biodiversity and agricultural soil management. Curr Opin Environ Sustain 4:523-528. https://doi.org/10.1016/j.cosust. 2012.06.004

Thorup-Kristensen K (2006) Effect of deep and shallow root systems on the dynamics of soil inorganic N during 3-year crop rotations. Plant Soil 288:233-248. https://doi.org/10.1007/s11104-006-9110-7

Thorup-Kristensen K, Magid J, Jensen LS (2003) Catch crops and green manures as biological tools in nitrogen management in temperate zones. Adv Agron 79:227-302

Tsiafouli MA, Thébault E, Sgardelis SP, de Ruiter PC, van der Putten WH, Birkhofer K, Hemerik L, de Vries FT, Bardgett RD, Brady MV, Bjornlund L, Jørgensen HB, Christensen S, Hertefeldt TD, Hotes S, Gera Hol WH, Frouz J, Liiri M, Mortimer SR, Setälä H, Tzanopoulos J, Uteseny K, Pižl V, Stary J, Wolters V, Hedlund K (2015) Intensive agriculture reduces soil biodiversity across Europe. Glob Chang Biol 21:973-985. https://doi.org/10.1111/gcb.12752

Van Ruijven J, Berendse F (2009) Long-term persistence of a positive plant diversity-productivity relationship in the absence of legumes.
Oikos 118:101-106. https://doi.org/10.1111/j.1600-0706.2008. 17119.x

Vos J, van der Putten PEL (1997) Field observations on nitrogen catch crops. I. Potential and actual growth and nitrogen accumulation in relation to sowing date and crop species. Plant Soil 195:299-309. https://doi.org/10.1023/A:1004281218996

Vukicevich E, Lowery T, Bowen P, Úrbez-Torres JR, Hart M (2016) Cover crops to increase soil microbial diversity and mitigate decline in perennial agriculture. A review. Agron Sustain Dev 36:48. https:// doi.org/10.1007/s13593-016-0385-7

Wichern F, Mayer J, Joergensen RG, Müller T (2007) Release of C and N from roots of peas and oats and their availability to soil microorganisms. Soil Biol Biochem 39:2829-2839. https://doi.org/10.1016/j. soilbio.2007.06.006

Wittwer RA, Dorn B, Jossi W, van der Heijden MGA (2017) Cover crops support ecological intensification of arable cropping systems. Sci Rep 7:41911. https://doi.org/10.1038/srep41911

Park W, Kim K-S, Jang Y-S, Lee K, Kim S-J, Ahn S-J, Hong SW, Lee Y$\mathrm{H}$ (2017) Variation in glucosinolate contents of cruciferous plants. Rec Nat Prod 11:185-192

Zhu B, Gutknecht JLM, Herman DJ, Keck DC, Firestone MK, Cheng W (2014) Rhizosphere priming effects on soil carbon and nitrogen mineralization. Soil Biol Biochem 76:183-192. https://doi.org/10. 1016/j.soilbio.2014.04.033

Publisher's note Springer Nature remains neutral with regard to jurisdictional claims in published maps and institutional affiliations. 